Animal Health Research Institute,

Assiut Regional Laboratory.

\title{
PREVALENCE STUDIES ON COCCIDIA OF GOATS IN ASSIUT GOVERNORATE WITH NOTES \\ ON SEASONAL VARIATION
}

(With 5 Tables and 1 Plate)

\author{
By
}

M. I. ARAFA

(Received at 22/12/2001)

دراسات عن مدى تواجد الكوكسيديا في الماعز في محافظة أسبيوط

يع الأشارة إلى الإختلافات الفصلية

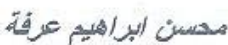

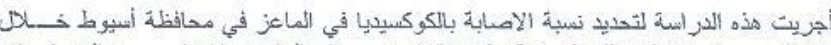

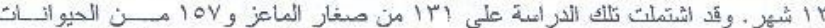

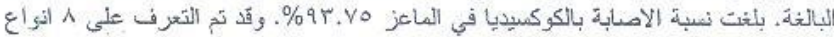

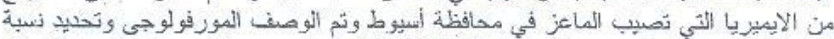

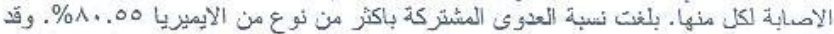

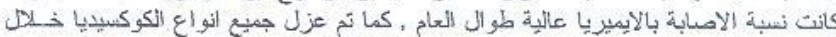

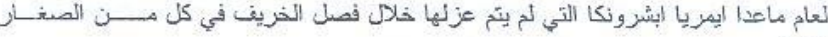

\section{SUMMARY}

Parasitological study was done to determine coccidial infection rates among goats in Assiut Governorate during 12 months period. The study included 288 goats (131 kids and 157 adults) in different localities of Assiut Governorate. Eimeria oocysts were found in $270(93.75 \%)$ of examined samples. Eight species of Eimeria were identified in the present work. The most common species was E.jolchijevi $(63.9 \%)$ and the lowest one was E.apshronica ( $8.3 \%)$. Mixed infection by more than one species was detected in $80.55 \%$. All species were detected allover the year except E.apshronica which was not detected in Autumn in both kids and adults. Morphological characters of each Eimeria species were described.

Key words:Coccidia, Goats. 


\section{INTRODUCTION}

Goats are widely distributed allover the world. In developing countries they are known as "the poor man"s cow" because they are used as a source of meat in addition to milk and mohair fiber production. Coccidia is one of the important parasites of goats especially in the growing kids (Matthews, 1999).

Smith and Sherman (1994) reported that Eimeria oocysts were widely prevalent in faeces of both normal and diseased goats of all ages, but the highest incidence of clinical disease occurred in kids. They added that, in the past. Eimeria species infecting goats and sheep were presumed to be the same as a result of close morphological similarity between the oocysts of Eimeria spp.

McDougald (1979) after well-controlled experiments demonstrated that each small ruminant host has its own host specfic Eimeria species that are not readily cross-infective. These results led to redescription and renaming of Eimeria spp. of goats.

Norton (1986) described nine species of Eimeria in English goats and the total incidence was $98 \%$. Matthewe (1999) stated that goats are affected by 12 species of Eimeria.

Yvore et al. (1980) recorded that a mixture of pathogenic spp. of Eimeria in kids produced haemorrhagic enteritis and papilloma like lesions in small intestine, while Gregory (1983) mentioned that coccidia which attacks the large intestine of ruminants produce lethal effects than the species which develope in small intestine.

In Egypt, goats are breeding in small numbers in villages or individualy in houses. Furthermore, knowledge about Eimeria of goats in Egypt was represented by only few authors (El-Shrif et al., 1959 and Otify, 1984).

The aim of the present study was to determine the incidence of Eimeria spp. in kids and adult goats, identification of different Eimeria spp. and study their seasonal variations in Assiut Governorate.

\section{MATERIAL and METHODS}

Random faecal samples from 288 goats ( 131 kids and 157 adult goats) were collected from different localities in Assiut Governorate during year 2000-2001. Faecal samples were collected in clean plastic cups, labeled and delivered directly to the laboratoy. 
Each faecal sample was examined macroscopically then microscopically by floatation technique with concentrated salt solution (Soulsby, 1982).

Oocysts of different Eimeria species were collected and mixed with $2 \%$ potassium dichromate solution and incubated at $27^{\circ} \mathrm{C}$ for sporulation.

The identification of different Eimeria species was done by reference to the descriptions given by Levine (1985), Norton (1986) and Smith \& Sherman (1994).

The size of different oocysts was measured by the use of eyepiece micrometer (Lawrence and Thomas, 1987) and illustrated by photomicrographs.

\section{RESULTS and DISCUSSION}

I- Incidence of Eimeria spp. in goats in Assiut Governorate:

Out of 288 goats examined in the present work, $270(93.75 \%)$ were infected with coccidian oocysts allover the year. This incidence included $127(96.95 \%$ ) of kids and $143(91.08 \%$ ) of adult goats (Table 1 ). This high incidence is considered one of the main characters of Eimeria infection in goats. In England, Norton (1986) recorded them in $98 \%$ of examined goats. In Czech Republic, Koudela and Bokova (1998) detected them in $92.2 \%$ of goats, while the prevalence reached $100 \%$ in South Africa (Harper \& Penzhorn, 1999). In Egypt, Otify (1984) detected them in $94.65 \%$ of examined goats. These high incidences of Eimeria could be due to adaptation and higher resistance of oocysts to the different environmental conditions, in addition to poor hygienic the different environ mentioned that Eimeria oocysts are quite resistant to environmental degradation, and are even more resistant when sporulation occurs.

II- Incidence of different Eimeria spp. in goats:

Eight Eimeria spp. were identified in the present work. The most common species were E.jolchijevi $(63.9 \%)$. E.herci $(59.7 \%)$, E.alijevi $(58.7 \%)$ and E.arlongi $(48.6 \%)$. The less frequently encountered species

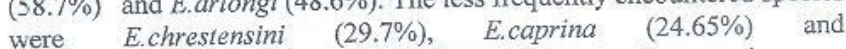
E.ninakohlyakimovae $(23.3 \%)$. The lowest infection species was E.apshrenica (8.3\%). (Table 4). E.arlongi, E.caprina and E.christensini were more abundant in kids than adults. 
The identification of different Eimerian oocysts depends on the close similarity of their characters and their dimensions with those previously mentioned by Soulsby (1982), Norton (1986) and Smith \& Sherman (1994) (Table 5) (Plate I).

Most of the present species were detected by several authors but with variable incidences (Norton, 1986; $0^{\circ}$ Callaghan, 1989; Kanyari, 1993; Koudela \& Bokova, 1998 and Jalila et al., 1998). This variation in incidence of infection may depend on the stage of potency of infection and immune state of the animals to each species.

Mixed infection by more than one sp. of Eimeria was detected in $80.55 \%$ of examined samples where it was $81.68 \%$ in kids and $79.62 \%$ in adults (Table 2). This result agrees with Otify (1984); Norton (1986) and Koudela \& Bokova (1998). Yvore et al. (1980) considered that healthy kids could support heavy infection with mixed species of coccidia but stress factors could precipitate disease. Smith \& Sherman (1994) however mentioned that concurrent infection with mutiple Eimeria sp. is the rule.

\section{III- Seasonal variation of Eimeria in goats:}

Incidence of Eimeria infection is considered high allover the year, where it ranged from $89.5 \%$ in Summer to $97.3 \%$ in Winter (Table 3). In kids it ranged from $92.7 \%$ in Summer to $100 \%$ in Autumn, Winter and Spring. In adult goats, it ranged from $80.95 \%$ in Summer to $96.1 \%$ in Winter. All species were detected allover the year except E.apshronica which was not detected in Autumn. These results could be attributed to the overcrowding of pens specially in cold weather, stress factors as weaning, change of food in addition to resistance of the oocysts to environmental conditions. These results agree with Otify (1984) and Smith \& Sherman (1994).

The present study cleared that there is a slightly difference in incidence of infection with Eimeria between kids and adults. These results could be attributed to the presence of kids with their dames specially during lactation, where adults act as a carrier for eimerian oocysts. Smith \& Sherman (1994) mentioned that age-related resistance to clinical coccidiosis is reported in all ruminants, but this immunity is relative (not absolute) so it does not eliminate infection but it effectively checks the rate of coccidia reproduction of oocysts.

From the above mentioned results it could be concluded that coccidia is still one of the serious problems for goats in Assiut 
Governorate. So strict hygienic measures especially that related to thorough cleaning of stables, collection and disposal of animal manure in addition to administration of suitable anticoccidial drugs should be applied to control of coccidial infection.

\section{REFERENCES}

El-Shrif, A.F.; Abdou, A.H. and El-Sawi, W.F. (1959): The incidence of parasitic infections among the farm animals of the Faculty of Agriculture, Alexandria. J. Egypt. Vet. Med. Ass. (3-4): 211220

Gregory, $M . W .(1983)$ : Host reaction to coccidia in the sheep and rabbit and their relevance to intestinal disease. $\mathrm{Ph}$. D. thesis, London Univ

Harper, C.K and Penzhorn, B.I (1999): Occurrence and diversity of coccidia in indigenous, Saanen and crossbred goats in South Africa, Vet. Parasit., 82 (1): 1-9.

Jalila, A.; Dorny, P.; Sani, R.; Salim, N.B. and Vercruysse, J. (1998): Coccidia infection of goats in Selangor, Peninsular, Malaysia Vet. Parasit., 74 (2-4): 165-172.

Kanyari, P.W. (1993); The relationship between coccidia and helminth infections in sheep and goats in Kenya. Vet. Parasit., 51 (1-2) 137-141.

Koudela, B. and Bokova, A. (1998): Coccidiosis in goats in the Czech Republic. Vet. Parasit., $76(4): 261-267$.

Lawrence, $R$. and Thomas, $G$. (1987): Parasites: A Guide to Laboratory Procedures and Identification. $1^{\text {st }}$ ed. American Society of Clinical pathologists Chicago, 110-111.

Levine, N.D. (1985): Veterinary Protozoology. $1^{\text {th }}$ ed.. Iowa State University Press. Ames.

Matthewe, J.G. (1999): Diseases of the Goats. $2^{\text {nd }}$ ed. Clarendon House Veterinary Center, Chelmoford, UK.

McDougald, L.R. (1979): Attempted cross-transmission of coccidia between sheep and goats and description of Eimeria ovinoidalis. J. Protozoology, 26: 109-113.

Norton, C.C. (1986): Coccidia of the domestic goat Capra hircus, with notes on Eimeria ovinoidalis and E.bakuensis from sheep Ovis aries. Parasitology, 92: 279-289. 
O'Callaghan, M.G. (1989): Coccidia of domestic and feral goats in South Australia. Vet. Parasit., 30 (4): 267-272.

Otify, Y.Z. (1984): Studies on coccidian parasites of goats. Ph.D. Thesis, Faculty of Vet. Med. Alex. Univ.

Smith, M.C. and Sherman, D.M. (1994): Goat Medicine. $1^{\text {th }}$ ed. Lea \& Febiger U.S.A.

Soulsby, E.J.L. (1982): Helminth, Arthropods and Protozoa of Domesticated Animals. $7^{\text {th }} \mathrm{ed}$. Bailliers Tindall.

Yvore, P.; Dupre, P.; Esnault, A. and Besnard, J. (1980): Experimental coccidiosis in the young goat: parasitic development and lesions. International Goat and Sheep Research, 1: 163-167. 
Assim Vet. Meed. J. Vol. t6 No. 92. Jumuary 2002

Table (1): Incidence of Eimeria in goat in Assiut

\begin{tabular}{|l|c|c|c|c|c|c|c|c|c|}
\hline & $\begin{array}{c}\text { No. of examined } \\
\text { animals }\end{array}$ & $\begin{array}{c}\text { Infected } \\
\text { animals }\end{array}$ & \multicolumn{2}{|c|}{$\begin{array}{c}\text { Non } \\
\text { infected } \\
\text { animals }\end{array}$} & \multicolumn{2}{|c|}{$\begin{array}{c}\text { Single } \\
\text { infection }\end{array}$} & \multicolumn{2}{|c|}{$\begin{array}{c}\text { Mixed } \\
\text { infection }\end{array}$} \\
\hline Kids & 131 & 127 & 96.95 & 4 & 3.05 & 20 & 15.75 & 107 & 84.25 \\
Adult goat & 157 & 143 & 91.08 & 14 & 8.89 & 18 & 12.59 & 125 & 87.41 \\
\hline Total & 288 & 270 & 93.75 & 18 & 6.25 & 38 & 14.07 & 232 & 85.93 \\
\hline
\end{tabular}

Table (2): Incidence of mixed infection of goats with Eimeria spp.

\begin{tabular}{|c|c|c|c|c|c|c|c|c|c|c|c|c|}
\hline & \multirow{2}{*}{$\begin{array}{c}\text { No. of } \\
\text { examined } \\
\text { Animals }\end{array}$} & \multicolumn{11}{|c|}{ No, of Eimeria spp. } \\
\hline & & 0 & 1 & 2 & 3 & 4 & 5 & 6 & 7 & 8 & $\begin{array}{l}\text { total mixed } \\
\text { infection }\end{array}$ & $\%$ \\
\hline Kids & 131 & 4 & 20 & 25 & 21 & 20 & 23 & 12 & 6 & $\cdot$ & 107 & 81.68 \\
\hline Adult goat & 157 & 14 & 18 & 31 & 30 & 25 & 18 & 17 & 3 & 1 & 125 & 79.62 \\
\hline Total & 288 & 18 & 38 & 56 & 51 & 45 & 41 & 29 & 9 & 1 & 232 & 80.55 \\
\hline
\end{tabular}

Table (3): Scasonal variation of Eimeria infection in goats

\begin{tabular}{|l|c|c|c|c|c|c|c|c|c|c|c|c|}
\hline \multirow{2}{*}{} & \multicolumn{3}{|c|}{ Summer } & \multicolumn{3}{c|}{ Autumn } & \multicolumn{3}{c|}{ Winter } & \multicolumn{3}{c|}{ Spring } \\
\cline { 2 - 13 } & Ex. & Inf. & $\%$ & Ex. & Inf. & $\%$ & Ex. & Inf. & $\%$ & Ex. & Inf. & $\%$ \\
\hline Kids & 55 & 51 & 92.7 & 18 & 18 & 100 & 23 & 23 & 100 & 35 & 35 & 100 \\
Adult goats & 21 & 17 & 80.95 & 52 & 48 & 92.3 & 51 & 49 & 96.1 & 33 & 29 & 87.9 \\
\hline Total & 76 & 68 & 89.5 & 70 & 66 & 94.3 & 74 & 72 & 97.3 & 68 & 64 & 94.1 \\
\hline
\end{tabular}


1.ssiut Vet. Med. J. Vol. 76 No. 92, Jamuary 2002

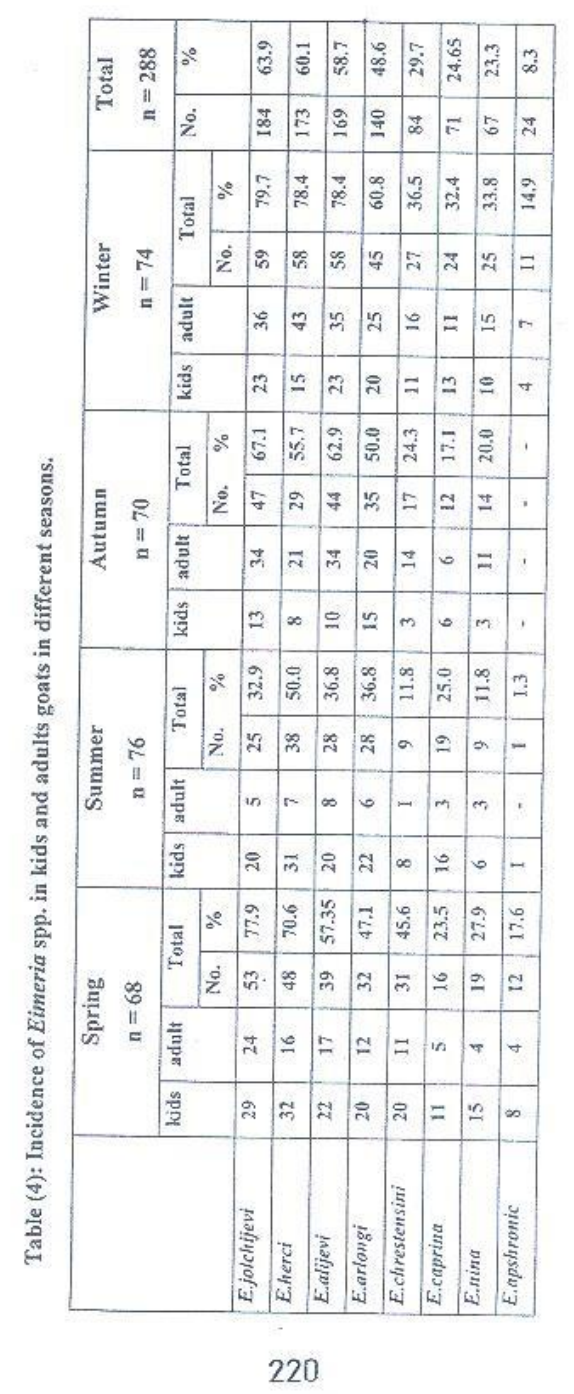


Assinf Vet. Med, J. Vol . $16 \mathrm{No}$. 92, Jamuary 2002

\begin{tabular}{|c|c|c|c|}
\hline 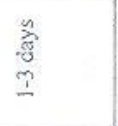 & 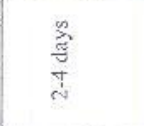 & 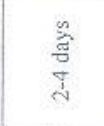 & 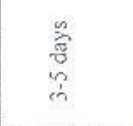 \\
\hline $\begin{array}{c}7 \\
⿱ \\
x \\
x \\
\infty \\
\infty\end{array}$ & $\begin{array}{l}\dot{0} \\
\times \\
\therefore \\
\stackrel{0}{0}\end{array}$ & $\begin{array}{l}\frac{m}{y} \\
x \\
\dot{8} \\
\dot{0}\end{array}$ & $\begin{array}{l}8 \\
8 \\
x \\
y \\
\alpha \\
0\end{array}$ \\
\hline$\stackrel{\circ}{-}$ & 3 & 9 & $\stackrel{\bullet}{-}$ \\
\hline $\begin{array}{l}\frac{n}{0} \\
\frac{0}{x} \\
m \\
\frac{j}{j}\end{array}$ & 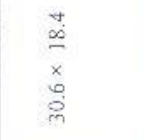 & $\begin{array}{l}\stackrel{0}{0} \\
\stackrel{5}{x} \\
\ddot{0}\end{array}$ & 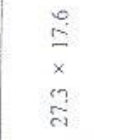 \\
\hline 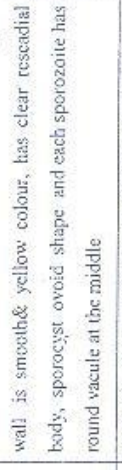 & 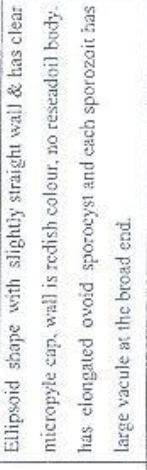 & 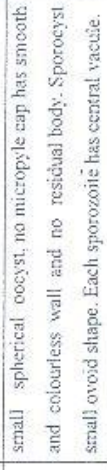 & 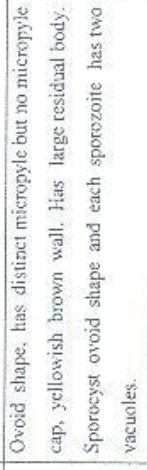 \\
\hline & 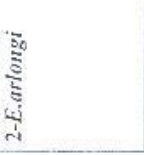 & 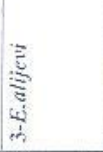 & 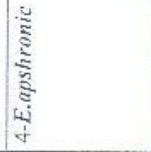 \\
\hline
\end{tabular}




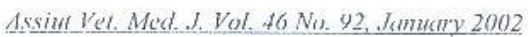

\begin{tabular}{|c|c|c|c|}
\hline 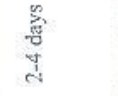 & $\begin{array}{l}\frac{0}{3} \\
\text { 咅 } \\
\text { d }\end{array}$ & 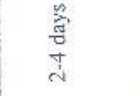 & 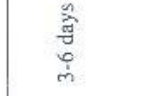 \\
\hline $\begin{array}{l}3 \\
x \\
x \\
2\end{array}$ & $\begin{array}{l}\infty \\
\dot{0} \\
x \\
0 \\
\dot{0}\end{array}$ & $\begin{array}{l}\vec{b} \\
\times \\
m \\
\stackrel{0}{0}\end{array}$ & $\begin{array}{l}\stackrel{+}{\sigma} \\
\dot{x} \\
\infty \\
\stackrel{\Xi}{\subseteq}\end{array}$ \\
\hline$\cong$ & $\because$ & $\because$ & $=$ \\
\hline $\begin{array}{l}\frac{\Delta}{0} \\
\frac{0}{x} \\
\infty \\
\stackrel{j}{j}\end{array}$ & $\begin{array}{l}\infty \\
\stackrel{d}{3} \\
\times \\
\dot{\Delta} \\
\dot{d}\end{array}$ & 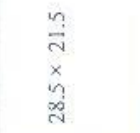 & $\begin{array}{l}\infty \\
\text { त्य } \\
\times \\
= \\
=\end{array}$ \\
\hline 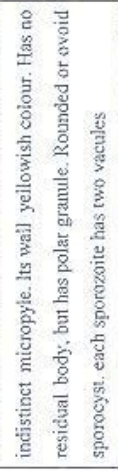 & 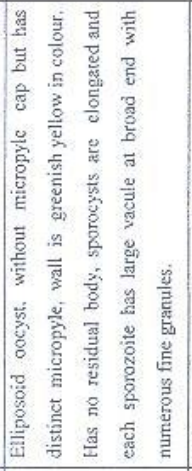 & 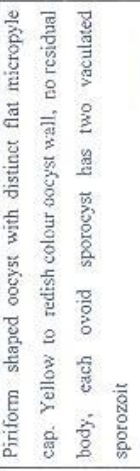 & 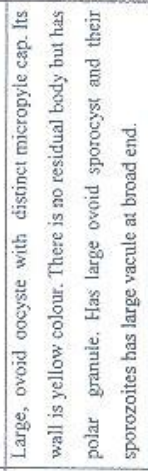 \\
\hline 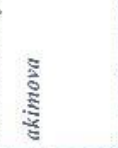 & 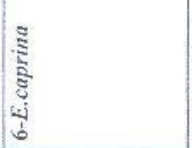 & है & 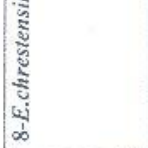 \\
\hline
\end{tabular}


Assiut Vet. Med. J. Vol. 46 No. 92. January 2002

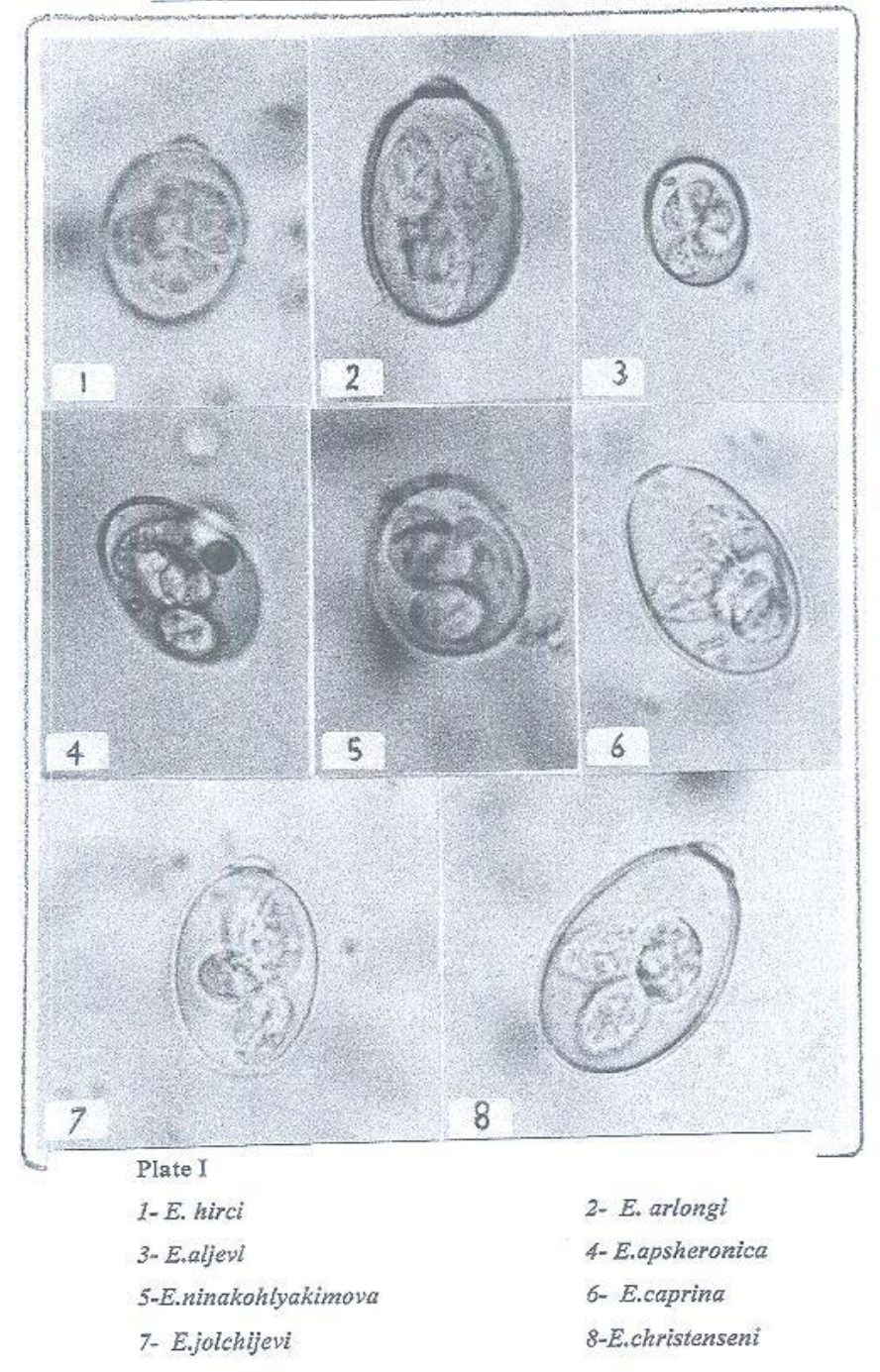

223 